\title{
Analysis of dairy cooperative movement in Haryana
}

\author{
Sumit Mahajan ${ }^{1}$, Janailin S Papang ${ }^{2}$, Avinash Ghule ${ }^{3}$, Shalini Arora ${ }^{1}$ and Indu ${ }^{1}$
}

Received: 23 June 2019 / Accepted: 24 July 2019 / Published online: 28 October 2019

(C) Indian Dairy Association (India) 2019

\begin{abstract}
Following the Anand Pattern, 6249 DCSs and 6 milk unions have been formed at village and district levels, respectively in the state of Haryana. At state level, marketing functions are administered by HDDCF formed in the year 1977. The present analysis was undertaken to indicate the weaknesses and suggest remedial measures in view of stiff competition faced by HDDCF from other market players. The present study is based on secondary data collected from various sources. The analytical methods used are tabular analysis and functional analysis. These arguments suggest the poor repayment capacity of loans taken, poor solvency and the growing inability to meet short term commitments of societies thereby affecting the profitability of societies. Decreasing number of functional societies and relatively lower average milk procurement by them is another area of concern. The reduction in real milk prices as well as comparatively lower milk prices pointed towards the relatively lower share of procurement by cooperatives in Haryana state as compared to other states.
\end{abstract}

Keywords: Dairy Cooperatives, HDDCF, Haryana

\footnotetext{
${ }^{1}$ College of Dairy Science \& Technology, LUVAS, Hisar, Haryana, India

${ }^{2}$ Division of DESM, ICAR-National Dairy Research Institute, Karnal, Haryana, India

${ }^{3}$ Institute of Rural Management, Anand, Gujarat, India

Sumit Mahajan $(\square)$

College of Dairy Science \& Technology, LUVAS, Hisar, Haryana, India E-mail: sumitzone2009@gmail.com
}

\section{Introduction}

The state of Haryana is known for milk production and has been rightly conferred as 'Milk Pail' of India. The state produced 9.81 million metric tonnes of milk in $2017-18$ which is $5.56 \%$ of total milk production in the country even though Haryana accounts for $1.4 \%$ of total geographical area of India. With per capita availability of $1005 \mathrm{~g}$ in 2017-18, the state is just behind Punjab (Government of India, 2018a). The economy of the state is predominantly based on agriculture and livestock forms $39.81 \%$ of agricultural GDP of state (Government of Haryana, 2018a). In the domain of dairy development, Haryana is well known for its productive milch bovines particularly the Murrah buffaloes and Hariana cows. The state stands $1^{\text {st }}$ in terms of buffalo productivity while, it is $2^{\text {nd }}$ in productivity of indigenous cattle which include Hariana, Sahiwal, Tharparkar, etc.

The cooperatives in Haryana follow the Anand pattern i.e. it has three tier system consisting of dairy cooperative societies at the village level, milk producers' cooperative union at the district level and Haryana Dairy Development Cooperative Federation (HDDCF), an apex body for the entire state.

The dairy cooperative movement started before formation of Haryana state with the formation of Dairy Cooperative Societies (DCSs) in some villages and in 1970, Haryana Dairy Corporation was set up which was subsequently replaced by the establishment of HDDCF year 1977. The federation is the apex body of the dairy cooperatives at the state level, having its headquarters at Panchkula. At present, there are six Milk Unions comprising 6249 DCSs having a total farmer membership of over 3 lakhs of which women membership is just $28.53 \%$. In total, there are 6 dairy plants in cooperative sector of the state with a processing capacity of 9.4 lakh LPD. The product mix of federation comprises Liquid Milk, Ghee, Paneer, Skimmed Milk Powder, Curd, Baby Food, etc. under the brand name of Vita.

Dairy cooperatives are the major market players in organised sector of dairy processing in Haryana and are also major supplier of milk and milk products to National Capital Region (NCR) region. In recent times, due to entry of other firms like Amul and Reliance, 
these cooperatives have been facing a stiff competition which necessitates a detailed analysis of dairy cooperatives in Haryana.

\section{Materials and Methods}

The present study is based on secondary data collected from various sources. Data on financial performance were taken from Department of Economic and StatisticalAnalysis, Haryana while data on manpower, functional societies, and purchase price were collected from Finance Department, Govt. of Haryana; Ministry of Agriculture and Farmer's Welfare, Govt. of India. The analytical methods used were tabular analysis and functional analysis. In functional analysis, following Gujarati (2003), Compound Annual Growth Rate (CAGR) has been calculated wherever required using the following regression equation:

$\ln Y_{t}=\beta_{1}+\beta_{2} t+u_{t}$

where,

$\ln Y_{t}=$ natural $\log$ of variable $Y_{t}$ whose $C A G R$ is to be calculated at timet

$\mathrm{t}=$ explanatory variable i.e. time (in year)

$\beta_{1}=$ intercept term

$\beta_{2}=$ regression coefficient for explanatory variable $\mathrm{t}$

$\mathrm{u}_{\mathrm{t}}=$ disturbance term

The CAGR (\%) is given as: $\left[\operatorname{antilog}\left(\beta_{2}\right) \text { “ } 1\right]^{* 100}$

\section{Results and Discussion}

\section{Financial performance of primary milk societies}

The following table depicts the financial performance of DCS over the years in Haryana:

The above table shows that number of societies in Haryana has increased rapidly over time. But in recent years, particularly after year 2008-09, the growth in number of societies has plateaued as most of revenue villages ${ }^{1}$ have been covered by dairy cooperatives. The number of farmer members also showed a similar trend depicting a rapid growth till late 2000s and thereafter the number has increased at a very meagre rate. Owned funds reflected the pattern of growth in societies and peaked in year 2007-08 and thereafter it never reached the levels of year 2007-08. Over the 10 year period from 2007-08 to 2016-17, the real value of owned funds showed a statistically non-significant CAGR of $8.04 \%$ which is an alarming situation as decrease in owned funds means that the societies have to depend on the external source of funds for financing and acquiring assets which increases its liability in the form of interest payments. Similar to pattern in owned funds, the real value of working capital of societies also displayed increase till year 2007-08 and thereafter decreased sharply with a statistically significant CAGR of $-24.01 \%$ for the period from 2007-08 to 2016-17 which is a worrying trend. A decrease in working capital indicates that either the current assets (like cash, receivables etc.) available with the societies have decreased or their current liabilities (short-term loans or payment to creditors) have increased, or a combination of both.

The real value of milk and milk products procured and sold by societies after tremendous growth in earlier years till year 200001 , have also shown a statistically significant decrease with a CAGR of $-3.83 \%$ and $-4.19 \%$, respectively during the period from 2007-08 to 2016-17 which would have affected the profitability of

Table1 Financial performance of dairy cooperative societies over time in Haryana

(at 2004-05 prices)

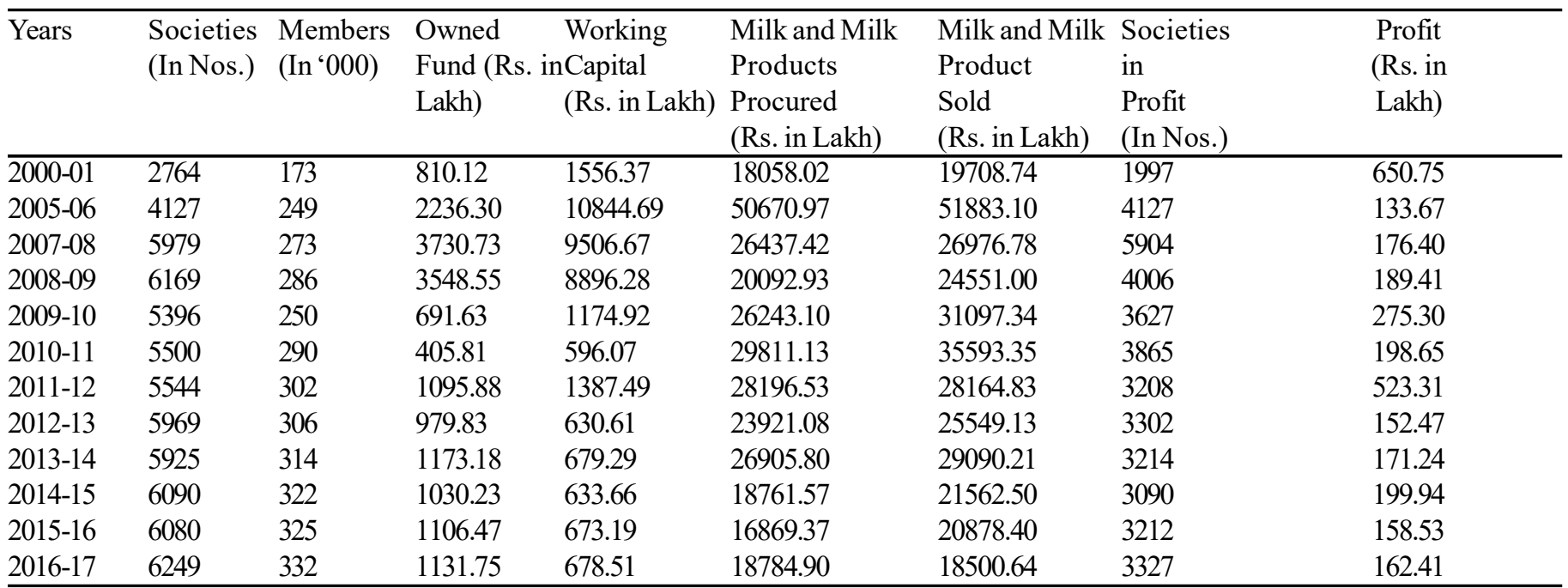

(Source: Government of Haryana, 2018a) 


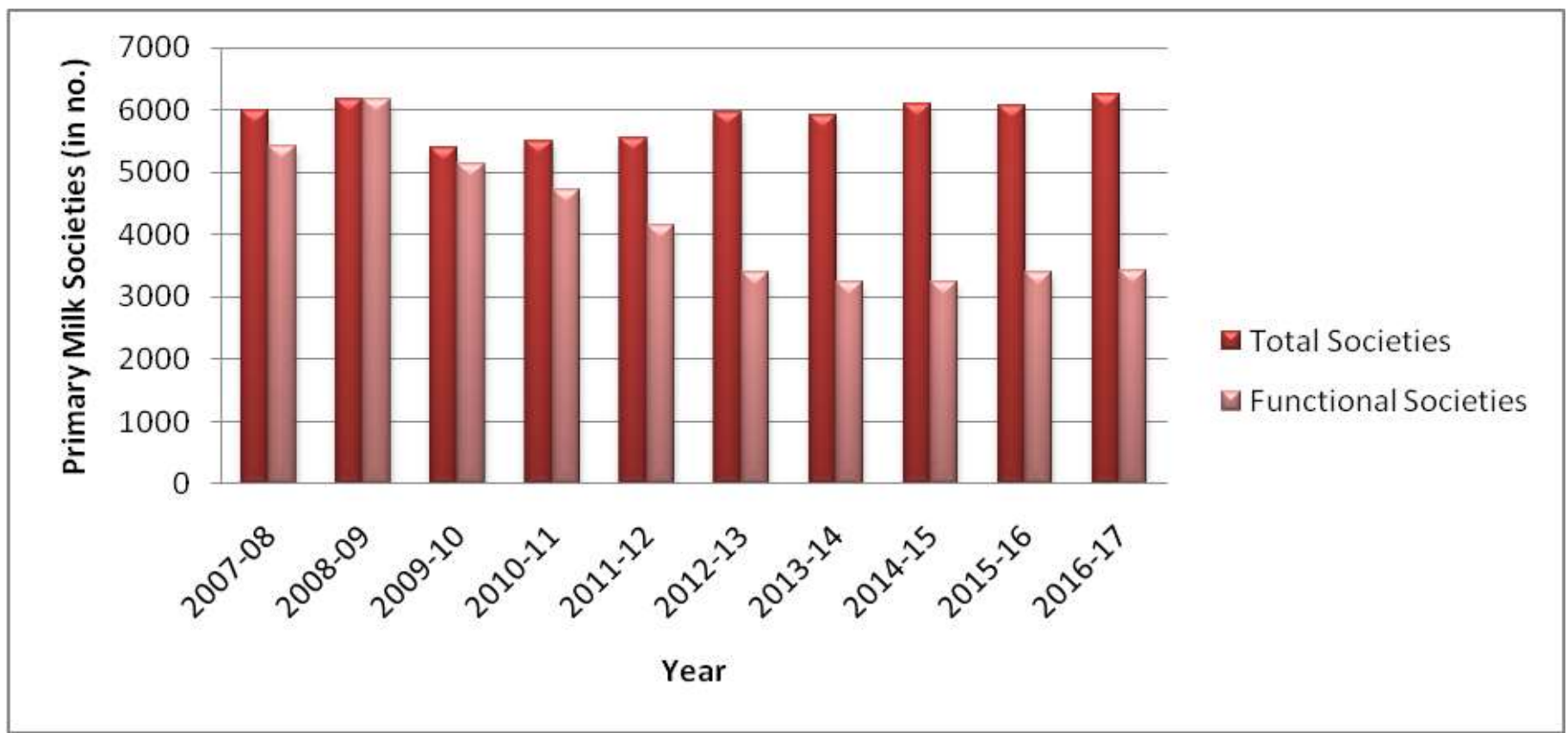

(Source: Government of Haryana, various issues of Profile of State public enterprises)

Fig.1: No. of Functional Cooperative Milk Societies in Haryana over time

societies and is confirmed by CAGR of $-3.14 \%$ for profitability of societies. The percentage of societies in profit also showed similar trends with nearly 100 per cent of them showing profits in mid 2000 s, but in recent years only half of the societies have shown profits which is concurrent with decrease in levels of working capital. These arguments suggest the poor repayment capacity of loans taken, poor solvency and the growing inability to meet short term commitments of societies thereby affecting the profitability of societies.

\section{Number of functional societies and women membership}

The number of functional societies as well as its proportion in total number of societies has decreased over time. From 91 per cent in the year 2007-08 to just 55 per cent in 2016-17, the proportion of functional societies has consistently gone down with a CAGR of $-7 \%$ reflecting the accelerated weakening of dairy cooperative movement in Haryana at the very grassroot level. Insert

The decline in functional societies can be explained by decrease in profitable societies, working capital, and owned funds. The HDDCF not only suffers from lower proportion of functional societies, the average milk procurement per functional DCS also works out to $166 \mathrm{KgPD}$ which is far less when compared to successful cooperatives like KOMUL where the corresponding figure is $536 \mathrm{KgPD}$.

It is obvious that decline in functional societies lead to lesser number of villages supplying milk to these societies and in 2016-
17 this number stood at 3104 which supplied milk to 3430 functional societies. The women membership of societies has been hovering around 25-28 per cent for the past 5 years. Amul asserts that it is successful because of its women members which makes it imperative for HDDCF to enhance the women membership and establishment of more women cooperative milk societies. The higher women membership will not only lead to higher procurement levels and also economic independence of women which is very important for a state like Haryana which still has strong patriarchal orientation.

\section{Milk procurement and milk prices offered by cooperatives in Haryana}

The average daily milk procured by cooperative societies in Haryana over the years has been depicted in fig.2. From fig.2, it is clear that milk procurement reached its highest after mid 2000s and till start of 2011 it maintained a constant level and in recent years the procurement level has declined even though the number of members has increased. The main reason for decline in procurement levels can be attributed to constancy in real prices of milk offered by cooperatives. The real purchase price of milk offered by cooperatives in Haryana decreased with a CAGR of $0.88 \%$ over the period from $2008-09$ to $2014-15$.

The percentage of milk procured by cooperatives as a percentage of total milk produced in major milk-producing states is displayed in Fig.3. It shows that Dairy cooperative movement is overwhelmingly strong in Gujarat where more than 50 per cent of milk produced is procured by cooperatives while states like 


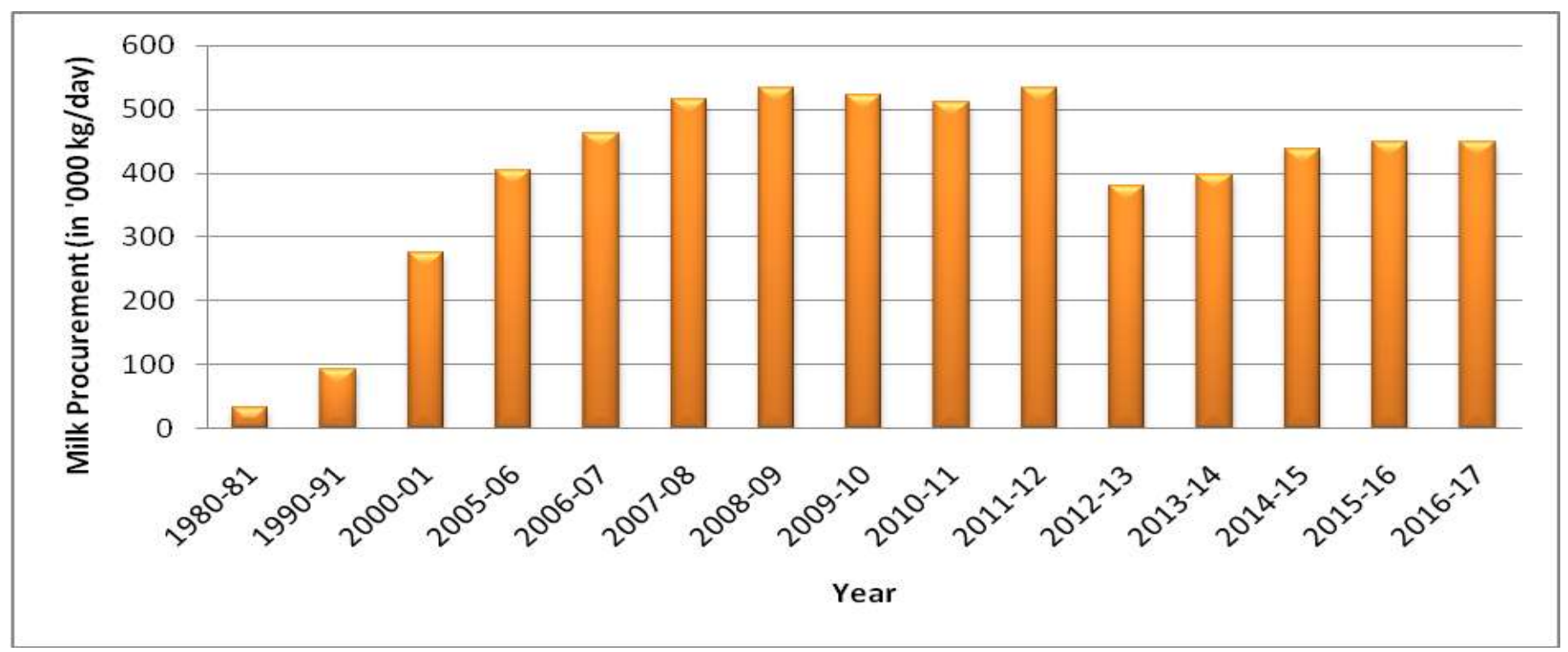

(Source: Government of Haryana, 2018a)

Fig.2 Average Daily Milk Procurement by Cooperatives in Haryana over the Years

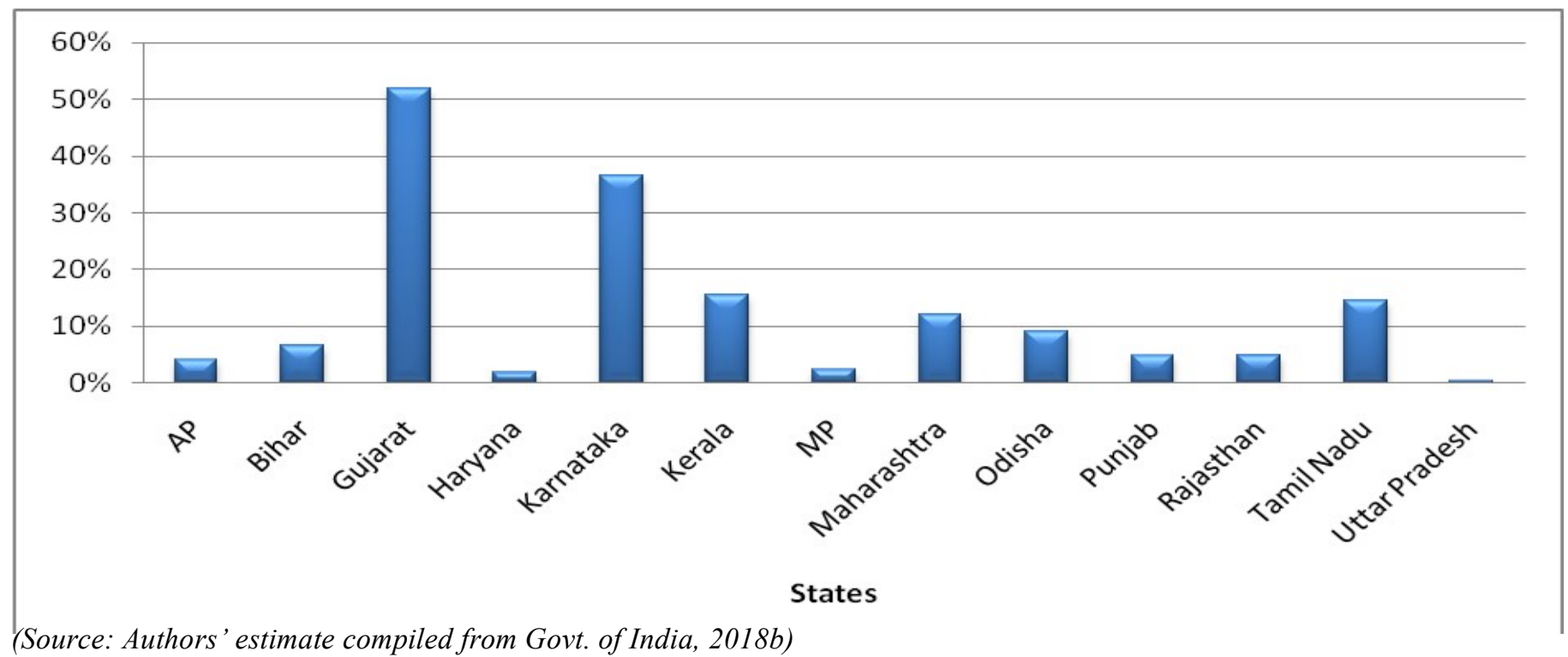

Fig.3 State-wise Milk Procured by Cooperatives as Percentage of Total Milk Produced in 2016-17

Haryana and UP fare poorly on dairy cooperative movement. Even the relatively lower milk producer states like Bihar and Odisha have higher procurement levels than Haryana not only in percentage terms but also in absolute values. As the main mover of the procurement, milk prices offered by state cooperatives were compared which are illustrated in Fig.4. It can be seen from the figure that milk unions in Haryana and UP offer very low prices for both cow and buffalo milk leading to lower procurement while milk unions in Gujarat and Kerala offer highest milk for buffalo and cow prices, respectively leading to higher percentage of procurement by cooperatives.

\section{Processing, chilling and installed capacity of dairy cooperatives in Haryana}

A comparison of chilling infrastructure of different state cooperatives is illustrated in Fig.5. The fig.5 reveals that dairy cooperatives in Haryana have one of lowest chilling capacities among the major milk producing states in India. Even cooperatives of low milk producing states like Odisha, Bihar, and Kerala have better milk chilling capacities than Haryana. This lower chilling capacity stems from lower milk procurement. Therefore, before enhancing the procurement levels, cooperatives need to invest 


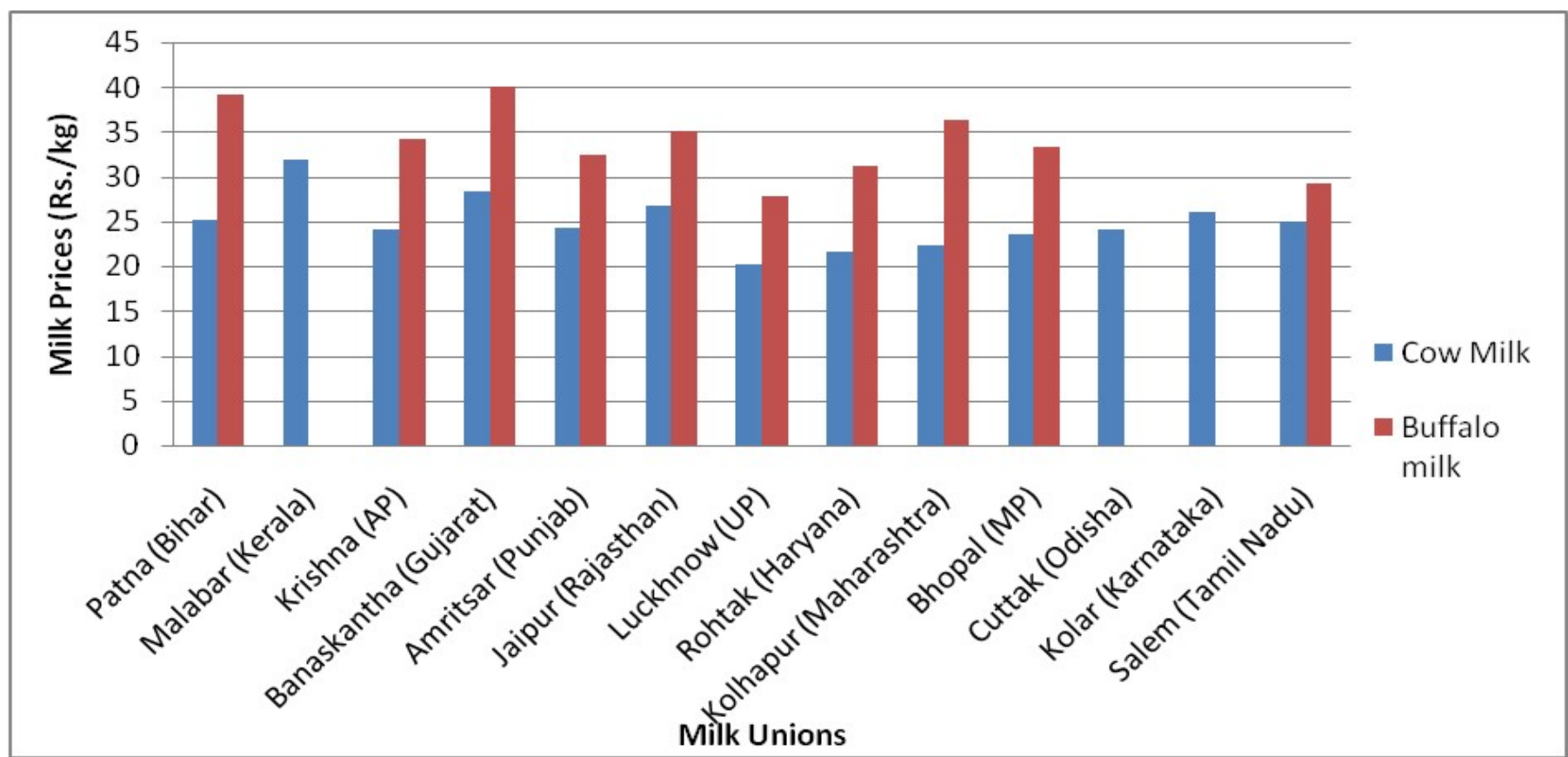

(Source: Anonymous, 2018)

Fig.4: Milk Prices offered by different milk unions in different states in year 2018

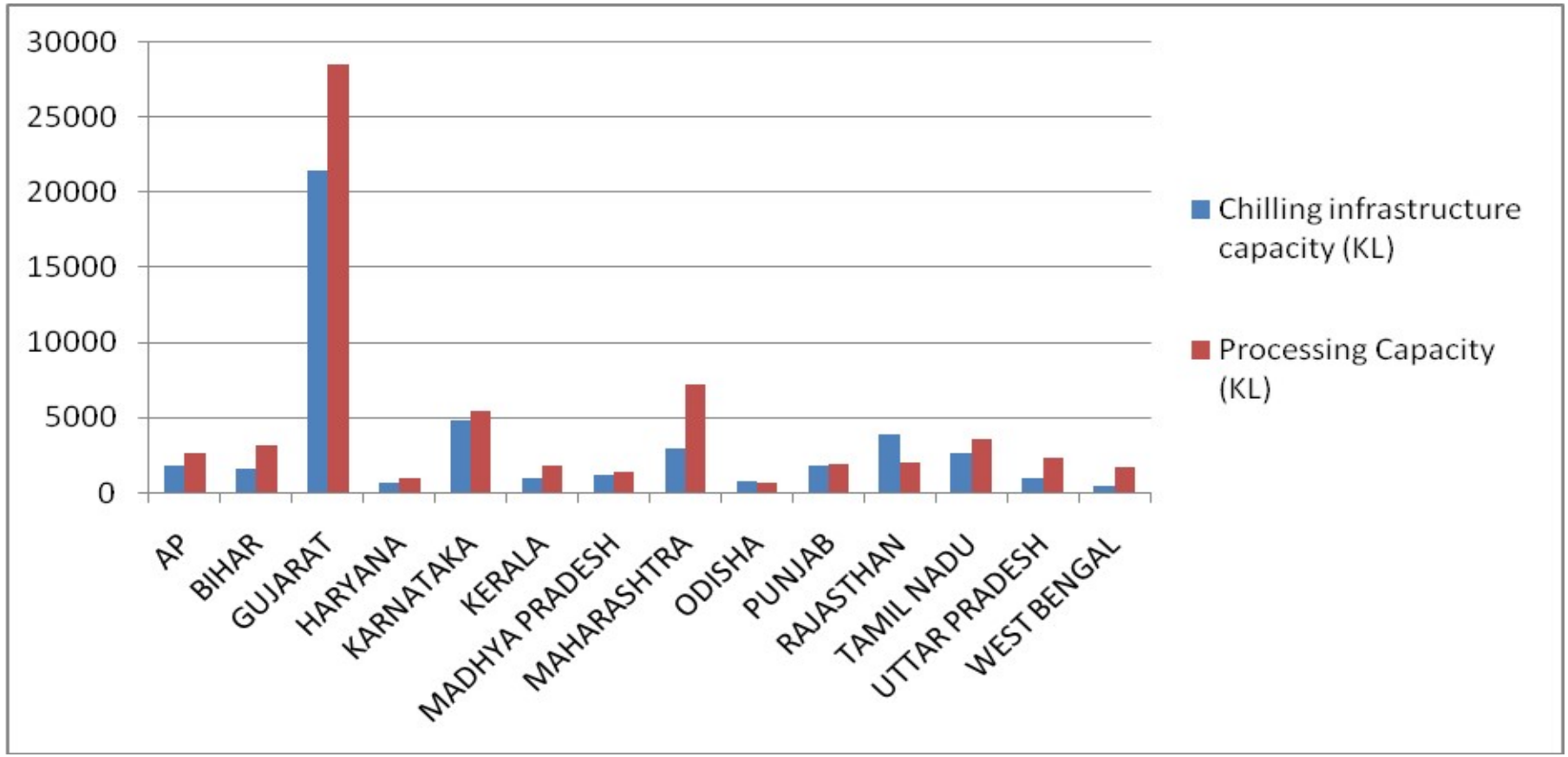

(Source: Government of India, 2018b)

Fig.5: Processing and Chilling Capacity of State Cooperatives in year 2016

heavily in chilling infrastructure thereby reducing the milk losses due to spoilage. Concurrent to the chilling capacity, the processing capacity of HDDCF is among the lowest in state dairy cooperatives which again indicate the consequent lower milk processing levels by the milk unions.
The neighbouring state cooperative of Punjab with which Haryana shares a social, cultural and geographical contiguity also fares much better in terms of chilling and processing capacities. While Haryana is lowest among the major state dairy cooperatives in terms of chilling and processing capacity, its 


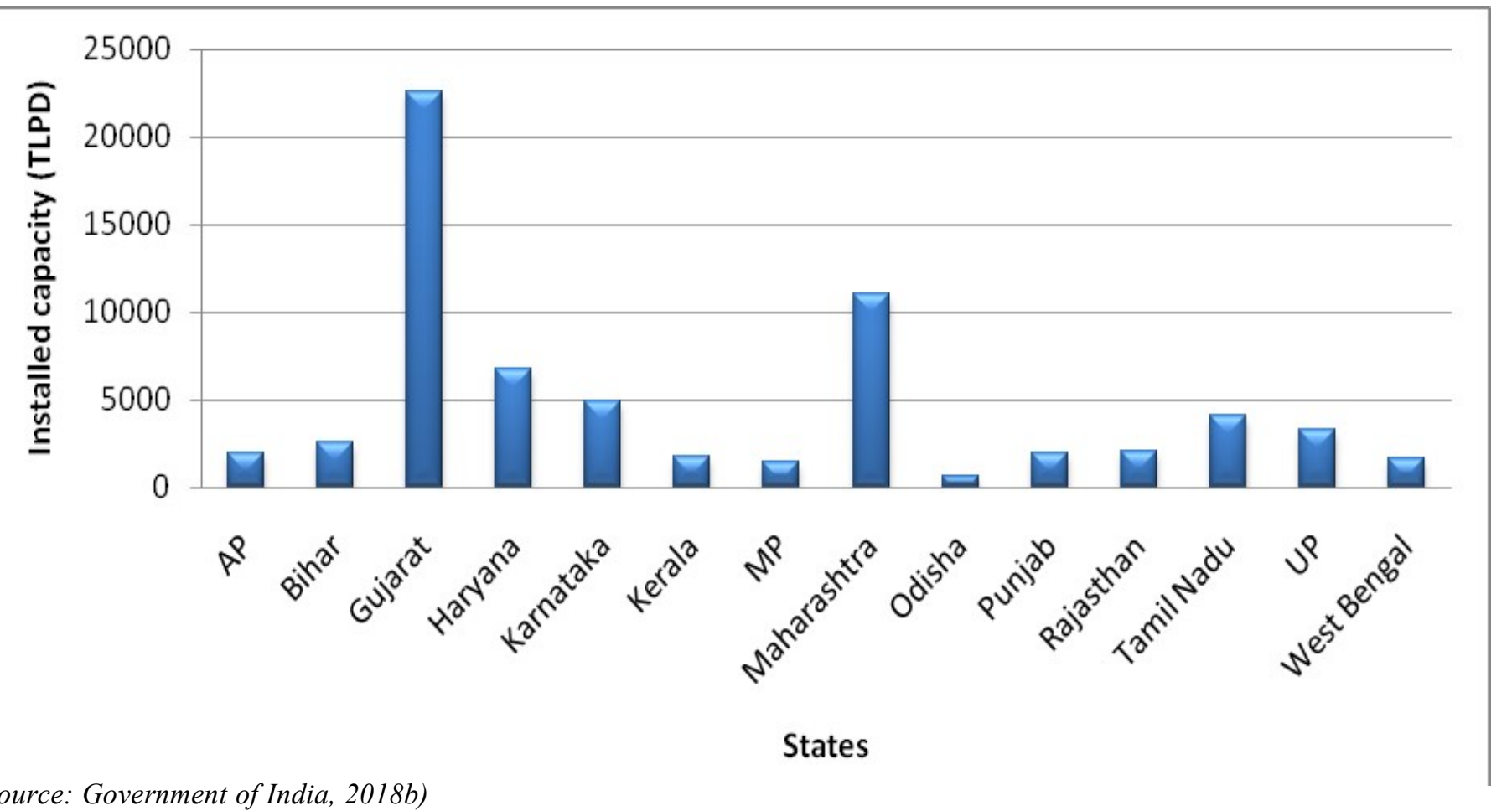

(Source: Government of India, 2018b)

Fig.6: Installed Capacity of State Dairy Cooperatives in year 2016-17

Table 2 Quantity of Milk and Milk Product Sold by the HDDCF over the Years

\begin{tabular}{llllc}
\hline Years & Ghee $(\mathrm{MT})$ & Butter $(\mathrm{MT})$ & Paneer $(\mathrm{MT})$ & Liquid milk (Lakh litres) \\
\hline $2008-09$ & 4947 & 445.00 & 601.41 & 1212.54 \\
$2009-10$ & 4864 & 231.00 & 466.00 & 1323.87 \\
$2010-11$ & 3731.00 & 219.36 & 462.04 & 1285.99 \\
$2011-12$ & 4388.00 & 237.40 & 538.04 & 1356.68 \\
$2012-13$ & 4202.71 & 314.16 & 530.98 & 1353.18 \\
$2013-14$ & 4720.70 & 332.89 & 609.10 & 1362.81 \\
$2014-15$ & 3708.67 & 447.62 & 640.53 & 1356.99 \\
$2015-16$ & 3674.56 & 248.29 & 659.92 & 1231.86 \\
$2016-17$ & 4003.27 & 224.75 & 739.55 & 1195.00 \\
\hline
\end{tabular}

installed capacity is the highest among the major state dairy cooperatives and is next only to Gujarat and Maharashtra i.e., even though the procurement levels, chilling capacity and processing capacity are at relatively lowest levels, the installed capacity is the opposite (Fig.6). This indicates that the federation has made huge investment in processing infrastructure which has not been made functional and is lying idle implying the gross mismanagement of funds on part of HDDCF.

\section{Milk and milk products marketed by HDDCF}

The main products of HDDCF are ghee, butter, skimmed milk powder (SMP), dahi, paneer, toned milk, condensed and sweetened milk, vita kheer etc. Table 2 depicts some of the major products marketed by HDDCF and their status over the years. It can be observed that sale of fat rich dairy products like ghee and butter has decreased substantially over the years with a CAGR of $-2.68 \%$ and $-1.24 \%$ during the period from $2008-09$ to $2016-17$. This decline in sales of fat-rich dairy products is in agreement with "urbanisation of diets" argument that due to changing lifestyle, growing income, increased health awareness and changing consumer preferences, people are moving away from traditional fat-rich dairy products. On the other hand, sale of Vita Paneer has shown a substantial CAGR of $4.51 \%$ during the period from 2008-09 to 2016-17. The increase in sales of Paneer might have come from increasing consumer preference for branded food products and due to predominance of vegetarian population in Haryana state for whom Paneer is a good source of protein and is very much relished particularly by other North Indians too. The amount of liquid milk marketed has more or less remained same due to poor growth in procurement. 
A major part of milk collected by the dairy co-op. in the state of Haryana is sold as liquid milk to Mother Dairy and Delhi Milk Scheme (DMS) and some urban centres of the state. It can be held that marketing of liquid milk is a major source of revenue generation. But numerous studies have suggested that profit margins of value added products are much higher than liquid milk itself. A lower proportion of liquid milk marketed to that of milk procured will ultimately suggest that sale of value-added products is on rise leading to higher profits for the state cooperative federation. This proportion is very low for successful cooperative like Gujarat (27\%) whereas in Haryana this proportion is much higher (74\%).

Some of the products like Lassi and Skimmed Flavoured Milk (SFM) marketed by HDDCF have shown good promise in recent years by showing increase in their sales. Sale of Lassi has shown a massive and statistically significant CAGR of $22.54 \%$ in 3 years period from 2014-15 to 2016-17 while sale of SFM clocked a significant CAGR of $7.72 \%$.

\section{Transportation cost}

Transportation cost is an important component of procurement cost, the other three being collection cost, chilling cost, and cost of reception of milk. Efficientmilk procurement by dairy plants minimise the cost of procurement and lead toimprovement in the milk procurement and marketing efficiency of dairy plants. The milk collected at various collection centres is either transported to chillingcentres or directly to the plant. The milk is transported by hired vehicles in milk cansto the chilling centres and directly to the plant from the areas around the milk plantand also milk is transported from chilling centres to the plant by the insulated milktankers.

The transportation cost as reported by HDDCF is Rs 0.81 per litre of milk in year 2014-15 (Govt. of Haryana, 2018b). A comparison with other milk unions in country revealed that cost of transportation of milk in Haryana is much higher than other successful dairy cooperatives like KOMUL which reported a transportation cost of Rs. 0.49 per litre of milk in 2014-15 (Anonymous, 2019).

\section{Manpower}

The management of manpower employed in any organisation is very important. The number of manpower employed should also be optimum so as to avoid undue financial stress. The total number of sanctioned posts in HDDCF is 968 out of which only 392 were filled with regular employees in 2016-17 (Government of Haryana, 2018b) which is less than even $50 \%$ of sanctioned posts. But on the other hand, the number of contractual employees was way higher than total sanctioned posts i.e. 1924. The additional contractual employees over and above the vacant sanctioned posts are not only causing the financial stress for the organisation, it is also leading to lower productivity of manpower thereby affecting the efficiency of organisation.

\section{Conclusions}

1. Need to increase the procurement: There is a need to increase the procurement from the farmers by revitalising the non-functional DCSs and by increasing the women membership. Blaming the entry of established market players like Amul wouldn't solve the problem. The plateauing of number of societies in general and consistent decrease in number of functional societies is a cause of worry. Therefore, the need of the hour is to revitalise the non-functional DCSs by optimising the input delivery (feeding, breeding, fodder development etc.); payments to producers on committed dates; training the new entrant staff; keeping party politics away etc. which will help in increasing the procurement from villages covered by non-functional DCSs. Increasing the women membership through capacity building and incentivising women centric DSCs shall be given prime importance which will not only increase the procurement but will also lead to social and economic upliftment.

2. Increase the profitability of societies: The real value of owned funds, working capital, milk and milk products procured and sold have declined over the time hampering the profitability of societies. The profitability of societies can be increased by making regular payments and reasons for societies under financial stress shall be investigated.

3. Increase in milk procurement prices: The decline in real milk prices offered by dairy cooperatives in Haryana can be regarded as main factor affecting the milk procurement by cooperatives. It was also seen that states where the milk prices offered by cooperatives were higher had a higher share of milk procurement in total milk production. Therefore, to increase the procurement, an increase in milk prices is of prime importance. The impact on profitability due to higher prices will be offset by resultant higher procurement volume. Further, the increase in procurement prices must be augmented with rise in retail prices as done by AMUL recently which will also help in buffering the impact of higher procurement prices on profitability.

4. Increasing the Chilling \& Processing capacities and utilising the installed capacity: Enhancement of chilling capacities will greatly affect the profitability of societies as loss of milk due to spoilage will be greatly reduced. Similarly increase in processing capacity will not only increase the profitability of unions but will also lead to utilisation of installed capacity which is lying idle to the tune of $57 \%$.

5. Optimising the product-mix and re-orienting the marketing strategy: The plateauing sales of traditional products like ghee, butter, and liquid milk and recent increase in sales of value added products like lassi and Skimmed Flavoured Milk has made it abundantly clear that there is a need to optimise the product-mix in favour of 
modern products. Further, becoming competitive in today's marketing environment essentially involves an enhanced role of advertising and making the packaging attractive. Unfortunately, HDDCF fares poor on both the fronts making it imperative to re-orient its marketing strategy. Therefore, there is a need to consult marketing experts who will not only suggest better resource utilisation (milk, machines, and manpower being the resource) by diverting more resources towards the products yielding better returns but will also enhance the sales of those traditional products whose sales have declined by building the brand value of VITA.

6. Reduction in transportation cost and route optimisation: The cost of transportation needs to be curtailed for increasing the efficiency. The reduction in transportation cost can be carried out using operation research which can optimise the routes for milk transportation.

7. Reduction in Strength of Contractual Employees and Hiring reforms: A reduction in strength of contractual employees over and above the vacant sanctioned posts will not only reduce financial stress for the organisation, it will also lead to higher productivity of manpower thereby affecting the efficiency of organisation. Further, through a robust recruitment process shall try to rope in professional dairy technologists which will prove fundamental to success of the organisation.

8. Learning from successful cooperatives: There is a strong need for HDDCF policy makers to learn from successful cooperatives of India such as those of Karnataka and Gujarat. Adetailed comparative analysis shall be done which will not only bring out the existing deficiencies but will also bring out the areas of new opportunities.
9. Third party and independent evaluation of investments: Looking into the investments made to increase the installed capacities, it is of paramount importance that ex-ante, midterm, and ex-post evaluation must be carried out for huge investments made in developing the installed capacities. The evaluations will not only ensure proper utilisation of funds, but will also give better idea of expected returns over the life of the proposed projects and whether the project achieved its intended targets/benefits in the proposed timeframe. It is equally necessary that these evaluations must be done by independent agencies which cannot be influenced by dairy cooperatives.

\section{References}

Anonymous (2018) Milk purchase price by cooperatives across various states, Pashu Sandesh, $22^{\text {nd }}$ March http://pashusandesh.com/milkpurchase-price

Anonymous (2019) Kolar-Chikkaballapura Cooperative Milk Producers Societies Union Limited, Kolar (KOMUL), Karnataka. http:// www.komul.coop/stastics/

Government of Haryana (2018a) Statistical Abstract of Haryana 201617, Department of Economic \& Statistical Analysis, Haryana

Government of Haryana (Various issues) Profile of State Public Enterprises, Finance Department, Haryana

Government of India (2018a) Basic Animal Husbandry and Fisheries Statistics 2018, Ministry of Agriculture and Farmer's Welfare, Department of Animal Husbandry, Dairying, and Fisheries, New Delhi

Government of India (2018b) National Action Plan for Dairy Development: Vision 2022, Ministry of Agriculture and Farmer's Welfare, Department of Animal Husbandry, Dairying, and Fisheries, New Delhi

Gujarati, DN (2003) Basic Econometrics. New York: McGraw Hill Book Co. 